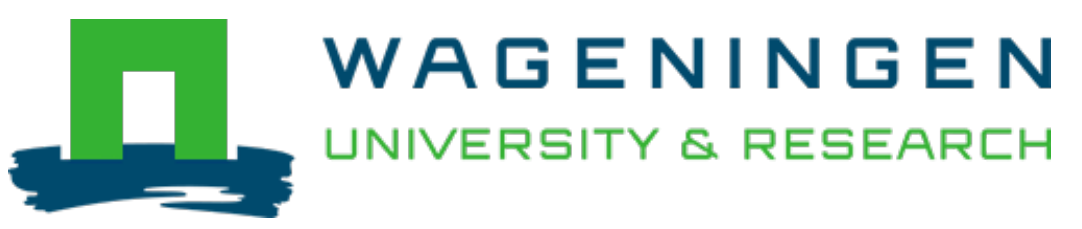

\title{
Transforming hydrosocial territories and changing languages of water rights legitimation: Irrigation development in Bolivia's Pucara watershed
}

\section{Geoforum}

Rocha López, Rígel; Hoogendam, Paul; Vos, Jeroen; Boelens, Rutgerd

https://doi.org/10.1016/j.geoforum.2019.04.012

This publication is made publicly available in the institutional repository of Wageningen University and Research, under the terms of article $25 \mathrm{fa}$ of the Dutch Copyright Act, also known as the Amendment Taverne. This has been done with explicit consent by the author.

Article 25 fa states that the author of a short scientific work funded either wholly or partially by Dutch public funds is entitled to make that work publicly available for no consideration following a reasonable period of time after the work was first published, provided that clear reference is made to the source of the first publication of the work.

This publication is distributed under The Association of Universities in the Netherlands (VSNU) 'Article $25 \mathrm{fa}$ implementation' project. In this project research outputs of researchers employed by Dutch Universities that comply with the legal requirements of Article $25 \mathrm{fa}$ of the Dutch Copyright Act are distributed online and free of cost or other barriers in institutional repositories. Research outputs are distributed six months after their first online publication in the original published version and with proper attribution to the source of the original publication.

You are permitted to download and use the publication for personal purposes. All rights remain with the author(s) and / or copyright owner(s) of this work. Any use of the publication or parts of it other than authorised under article $25 \mathrm{fa}$ of the Dutch Copyright act is prohibited. Wageningen University \& Research and the author(s) of this publication shall not be held responsible or liable for any damages resulting from your (re)use of this publication.

For questions regarding the public availability of this publication please contact openscience.library@wur.nl 


\title{
Transforming hydrosocial territories and changing languages of water rights legitimation: Irrigation development in Bolivia's Pucara watershed
}

\author{
Rígel Rocha López ${ }^{\mathrm{a}, *}$, Paul Hoogendam ${ }^{\mathrm{b}, 1}$, Jeroen $\operatorname{Vos}^{\mathrm{b}, 1}$, Rutgerd Boelens ${ }^{\mathrm{b}, \mathrm{c}, 2}$ \\ ${ }^{a}$ Andean Centre for Water Management and Use (Centro AGUA), Universidad Mayor de San Simon, Av. Petrolera Km 4.5, Cochabamba, Bolivia \\ ${ }^{\mathrm{b}}$ Department of Environmental Sciences, Wageningen University, Droevendaalsesteeg 3, 6708PB Wageningen, the Netherlands \\ ${ }^{\mathrm{c}}$ Centre for Latin American Research and Documentation/Department of Geography, Planning and International Development Studies, University of Amsterdam, the \\ Netherlands
}

\section{A R T I C L E I N F O}

\section{Keywords:}

Hydrosocial territories

Languages of water rights legitimation

Legitimacy

Water rights

Irrigation

Bolivia

\begin{abstract}
A B S T R A C T
Comprehending the context and history-based allocation and distribution of water use rights for irrigation is crucial for understanding social and agricultural dynamics in (semi)arid regions. Irrigation water rights are socio-legal constructs that, for their materialization, depend on the legitimacy, authority and powers backing their claims. We show how the recent conceptual notion of "hydrosocial territories" enables examining water rights claims as expressed in diverse and divergent "legitimation languages". Water rights and their legitimation languages are embedded in site-particular normative dynamics, cultural-political histories and changing socionatural configurations. This article focuses on Bolivia's Pucara watershed to examine the historical shifts in legitimizing water use rights, these claims' social acceptance, and their materialization in hydraulic infrastructure and access to water. The article analyzes three historical periods in which stakeholders sustain different ways to legitimize and defend their water rights. In the first (1950-1978), acquiring rights was sustained through "hydraulic property" relationships: rights-creation by investing in infrastructure development. In the second (1978-1995), a shift takes place to more territorially-oriented claims over water rights in response to governmental attempts to reorganize hydrosocial territories. In the third period (1995-2017), steered by indigenous communities' wider political emancipation processes and the municipalization policies, territorial claims over water sources and use rights have become decisive in the struggle over water. We show that, to enhance useroriented irrigation development, it is necessary to understand besides the positions, interests and power structures, also the multiple languages of water rights legitimation that underlay water control and that trigger either conflict or collaboration.
\end{abstract}

\section{Introduction}

Irrigation plays a fundamental role in development policies in Bolivia. It is one of the main supports that rural families request from the government (VRHyR, 2013). Through the implementation of irrigation projects, the state intends to provide, increase and control water supply for food production, increasing land's productivity and economic benefits of agricultural activity for rural families, contributing in this way to the national policy of sovereign food security (Ministerio del Agua, 2007). The implementation of irrigation projects seeks, on the one hand, to capture new water sources and expand irrigated land and, on the other, to improve and reorder traditional peasant irrigation systems to establish "more efficient, productive" irrigation water use and management. Most government-financed irrigation projects include building dams, inter-basin water transfers, improving and expanding hydraulic infrastructure and irrigation areas, favoring zones with greater agricultural potential (Ministerio del Agua, 2007; VRHyR, 2013).

Throughout history, peasant communities of the Andean Region countries have ordered and mutually connected their available resources (natural, material, human, etc.) in highly diverse ways, shaping culturally-specific forms of irrigation water management to reproduce their livelihoods (e.g., Gelles, 2000; Lynch, 2012; Orlove and Caton, 2010; Paerregaard, 2013; Rasmussen, 2015). By constructing specific

\footnotetext{
* Corresponding author at: 4926 Cochabamba, Bolivia.

E-mail addresses: rigel.rocha@umss.edu.bo (R. Rocha López), hoo@ces-bolivia.com (P. Hoogendam), jeroen.vos@wur.nl (J. Vos), rutgerd.boelens@wur.nl (R. Boelens).

${ }^{1}$ Present address: P.O. Box 47, 6700AA Wageningen, the Netherlands.

${ }^{2}$ Present address: PO Box 15629, 1001NC Amsterdam, the Netherlands.
} 
relationships with their hydrosocial context, peasant communities have developed their own particular, culturally embedded hybrid rules, norms and organizational entities to access and control water resources, which become manifest in the ways they struggle to defend and demand recognition of their water rights vis-à-vis other user groups and society at large (Boelens, 2015). Despite their complexity, diversity and grounding in particular histories, cultures and power relationships, conventional academia and dominant policy-making have analyzed water rights mostly in narrowly defined technical, economic and legalist ways - influential being the formal water law perspectives, technocratic engineering schools and economicist neo-liberal and new-institutionalism theories. Rather than trying to scrutinize how water rights actually work in practice - as developed and deployed dynamically by hugely diverse water cultures, these modernist-rationalist water rights schools commonly have aimed to prescribe how water rights should look like. Their frames provide, at once, the analytical tools to formulate and identify water rights and the measuring sticks for evaluating, judging and correcting presumably 'inappropriate' rights and water governance behavior (e.g., Roth et al., 2005, 2015).

In this article, we deploy the recent concept of hydrosocial territories (Boelens et al., 2016) to shed new theoretical light on this dynamic arena of water rights claims. We show how different groups conceptualize and imagine their territory in different ways, and based on this conceptualization, they strategically use particular water rights legitimation languages to strengthen their water claims and materialize their wished for hydrosocial territory. As we outline further in the next section, this analytical notion views the physical, social, political and symbolic domains of water management, entwined in particular territorial, multi-scalar configurations (Hommes and Boelens, 2017, 2018; Hommes et al., 2016; Marks, 2019; Seemann, 2016); whereby different actors imagine, design, strategize, and intend to construct and defend this territory in particular ways (Hoogendam, 2018; Hulshof and Vos, 2016). Socially imagined, strategically planned, and symbolically and physically materialized territory informs the claims they make: to the territory's resources and to the legitimate authority they argue to have to use and govern these resources (Bebbington et al., 2010; Goldman and Narayan, 2019; Sikor and Lund, 2009). Therefore, hydrosocial territories are dynamic, fragmented, disputed, always in the make, and go beyond just a legally recognized and physically constructed communal or state territory and its resources, boundaries and relationships.

Any intervention or change in water management and access conditions (such as those promoted by government-led or community-initiated irrigation projects) necessarily involves changes in the ecological, social and technological elements of the hydrosocial territory, affecting different groups of people in different ways. Therefore, diverse conflicts tend to arise from attempts to install new forms of ordering the hydrosocial territory, in particular (but not exclusively) in response to intentions and interests largely external to local understandings and acceptance. Many of these conflicts are related with struggles over rights to water and infrastructure, inclusion/exclusion of water right holders, disputes over the contents of water rules and rights and over local authority (Rocha et al., 2015; Roth et al., 2015; Van Koppen, 1998; Zwarteveen et al., 2005), as well as contestation vis-a-vis external encroachment and governance control projects (Budds and Hinojosa, 2012; Duarte-Abadia et al., 2015; Hidalgo et al., 2017; Hidalgo-Bastidas et al., 2018; Rocha López et al., 2019). Many of these conflicts also arise among different user communities. Behind all these water rights battles, changing and divergent languages of water rights legitimation play an important role.

Focusing on irrigation development in the Pucara watershed in central Bolivia, the article argues that along with irrigation development processes, multiple languages of water rights legitimation are created and used in multi-scalar political scenarios of struggles around water control. This becomes particularly apparent in the analysis of the historical construction and improvement of hydraulic infrastructure in and by peasant irrigation systems, which has led to complex overlapping and conflicting hydrosocial territories. Basic to the construction of hydrosocial territories are the different forms of defense and legitimization of claims over water access and water-based decision-making. Specifically, in the Pucara watershed case, the article focusses on how the legitimation of water rights has changed from 'hydraulic property creation' ${ }^{3}$ to 'territorial claims'. ${ }^{4}$

The next section discusses the article's central concepts, highlighting the inter-relationship of hydrosocial territorial configuration and the struggles for water rights legitimation. The third section introduces the Pucara watershed and the methodology applied for data collection. The fourth section describes irrigation development in the Pucara watershed, considering three periods: from the hacienda up to community control of irrigation water (1950-1978), the period of planned re-ordering of peasant irrigation systems through state intervention (1978-1995) and the period of territorializing water (1995now). Throughout this historical process, water and water control have been defended in different and divergent modes, in accordance with the nature of the hydrosocial territories established. The final section discusses results and draws conclusions.

\section{Hydrosocial territories and languages of water rights legitimation}

Research on water rights has developed significantly during the past decades. While in the Western legal tradition water use rights were (and often still are) rather strict individual or collective entitlements "to abstract or divert and use a specific amount quantity of water from a natural source; to impound or store a specified quantity of water behind a dam; or to use water in a natural source" (Hodgson, 2004:14); and while US-based literature may often concentrate on two basic water rights principles ("prior appropriation of water" in the relatively arid Western States, and the "riparian doctrine" in the more humid Eastern States) (e.g., Hutchins, 1971; Sax, 1990); most contemporary research points at the far greater diversity and complexity of water rights realities around the world. Schlager and Ostrom (1992) introduced the idea of the "bundle of water rights" which tie together different principles of access, withdrawal, exclusion and obligations related to water use, but very importantly, also relate the water rights to the right to manage water resources and decide about their distribution systems. An important related insight was the idea of "hydraulic property creation" (e.g., Coward, 1983, 1986; Gerbrandy and Hoogendam, 1998, 2002; Guevara-Gil et al., 2010; Vos et al., 2006), whereby groups of water users gain the right to use water by investing labour (and other resources) in the construction of diversion and distribution works, and maintain their use rights by investing labour in the maintenance and repair of the infrastructure. In later work, the infrastructure related argument was extended to the catchment area where water flows are controlled and 'humanized'. This broader analysis argues that by planning, constructing, operating and maintaining infrastructure to control water, people construct and reproduce water territories or hydrosocial territories as explained below (Boelens and Vos, 2014).

Increasing water scarcity, growing competition and conflicts, intensifying groundwater use, and responses to the rise of new policies (e.g. market-environmentalism) added to water governance complexity. In this context, a growing body of studies of actual water rights regimes in colonial and post-colonial countries revealed situations of deep legal

\footnotetext{
${ }^{3}$ Hydraulic property refers to water rights (privileges to access water, infrastructure, decision-making) claimed and gained by users through their collective and individual investments (labor and capital) in the construction and maintenance of hydraulic infrastructure (Boelens and Vos, 2014; Coward, 1983, 1986).

${ }^{4}$ Territorial claims refer to the socio-territorial rights over water sources originating in or flowing through a socio-geographical territory (Boelens, 2015).
} 
pluralism (Benda-Beckmann, 2007; Meinzen-Dick and Pradhan, 2005; Spiertz, 2000), where in one political-geographic location several legal systems operate, overlap and interact. In policy-documents, this quickly resulted in classifications of water rights regimes as pertaining to rather clear-cut categories and legal-administrative frameworks, like "community-based", "state-led" or "market-based" (e.g., Bruns and MeinzenDick, 2005; Ringler et al., 2000). But in-depth studies show how these local rights systems rather need to be conceptualized as 'hybrids' because they combine local customary rights with colonial, governmental and international normative elements (e.g., Benda-Beckmann, 2001, 2007; Jackson, 2018; Wilson and Inkster, 2018). Most of these water struggles originate from the (conflict-ridden) co-existence of, and interaction among, different socio-legal frameworks (Boelens et al., 2005; Roth et al., 2015; Zwarteveen et al., 2005).

The study of the diversity of water rights regimes around the world led to the identification of a number of basic principles to legitimately obtain and maintain water rights. Boelens (2015), for example, mentions: (1) concessions granted by the state, (2) prior appropriation and/ or historic rights, (3) socio-territorial rights and/or riparian rights, (4) transfer of rights (sale, barter, donation, inheritance, etc.), (5) acquisition of rights by force, and (6) hydraulic property creation. This debate on locally recognized legitimacy of principles to acquire and practice water rights, obviously, directly connects to the debates on divergent water values, meanings, and governance principles (Castro, 2007; Cleaver, 2000), the related languages of valuation and legitimation (Duarte-Abadía and Boelens, 2016; Martinez-Alier, 2009), and also "nature's right to water" (Rawson and Mansfield, 2018; Valladares and Boelens, 2017). Since different languages of valuation often are not commensurable, legitimation and prioritization of water rights becomes a matter of political power.

In this article, we use the concept of hydrosocial territories as a novel theoretical concept to look at struggle over water, infrastructural projects and water rights. It shows the dynamics of different overlapping hydrosocial territories and the related languages of legitimation of water right claims. The notion of "hydrosocial territory" inter-relates the control of water sources, catchment areas, the hydraulic infrastructure used to conduct and distribute water, and the other water related resources, with the actor groups who manage, use, and/or steer the water, its knowledge, stories and imaginaries, as well as with the broader political-geographical scales and governance entities. In a given socio-natural setting (such as the Pucara watershed), multiple hydrosocial territories exist, representing the diversity and heterogeneity of social groups involved in trying to design, shape and strategize the configuration of the watershed, in accordance with their imaginaries and interests, often competing with each other (Baletti, 2012; Hoogesteger et al., 2016). Therefore, "hydrosocial territory" is conceptualized as the "contested imaginary and socio-environmental materialization of a spatially bound multi-scalar network in which humans, water flows, ecological relations, hydraulic infrastructure, financial means, legal-administrative arrangements and cultural institutions and practices are interactively defined, aligned and mobilized through epistemological belief systems, political hierarchies and naturalizing discourses" (Boelens et al., 2016:2).

The underlying conceptualization enables examining how territorial politics finds expression in encounters of diverse stakeholders with divergent economic, cultural and political-geographical interests in water (Meehan, 2013; Pfaffenberger, 1988; Swyngedouw, 1999; Van der Ploeg, 2008; Vos et al., 2006; Vos and Boelens, 2014). Aiming to strengthen the specific claims they have in water control - expressed in dynamics of frictions and alignment, of collaboration and competition, and of subordination and resistance - these actors "continuously recompose the territory's hydraulic grid, cultural reference frames, and political-economic relationships" (Boelens et al., 2016:1). The hydrosocial territory concept allows to examine how different modes of power work to governmentalize and repattern water-connected spaces and places - triggered by diverging imaginaries and interests (see e.g.,
Bleeker and Vos, 2019; Duarte-Abadía and Boelens, 2019; Goldman and Narayan, 2019; Hoogendam, 2018; Marks, 2019; Seemann, 2016; Vos and Hinojosa, 2016).

Conflicts over irrigation intervention projects can be interpreted as struggles to establish new hydrosocial territories or reconfigure existing ones (e.g., Rocha López et al., 2019). As we will highlight, to gain control over water and decision-making, social groups within the watershed struggle over all constituent elements of the hydrosocial territory and interfere in the physical, social, political and symbolic domains, employing specific languages to legitimize their (claims to) control (cf. Castro, 2007; Duarte-Abadía and Boelens, 2016; Harris and Roa-García, 2013; Hulshof and Vos, 2016). These languages are derived from their worldviews and discourses, sometimes unconsciously but often presenting arguments in a strategic way. They are aware that arguments that 'resonate' with the worldview of others (and in particular with that of decision makers on policy and projects), can be more effective in legitimizing and materializing their own claims (see Benford and Snow, 2000).

The compositions, linkages and delimitations of hydrosocial territories are influenced by societal norms and power relationships (see e.g., Agnew, 1994; Baletti, 2012; Elden, 2010; Escobar, 2008; Mancano, 2009). Here, water rights - their sociomaterial substance, sociolegal relationships and epistemological conceptualization - are fundamental elements of the hydrosocial territorial network. They are immersed in social, political and cultural inter-relationships that determine the nature, function and meaning of water and are closely related with, for instance, rural communities' and/or water governors' and water experts' identities (Boelens and Seemann, 2014; Perreault, 2008; Rodríguez-de-Francisco and Boelens, 2015, 2016). Beccar et al. (2002) assert that water rights constitute an expression of agreements about the legitimacy of water userś claim to water. These legitimacy agreements are negotiated based on a variety of reference frameworks or languages of water rights legitimation (see Boelens and Doornbos, 2001; Gerbrandy and Hoogendam, 1998). ${ }^{5}$ The concept of legitimacy involves the formal and informal ways in which these processes, structures and authorities are validated and consequently empowered (Gearey and Jeffrey, 2006). What follows is that, in the arena of struggles over access to and control over water, different languages of water rights legitimation compete. Understanding the changing languages of water rights legitimation and how these underlay peasant communities' political actions to re-order and defend their hydrosocial territories, helps to better understand the diverging positions, interests and power structures that prevail in irrigation development processes.

As the article shows, it is common to find multiple overlapping and competing hydrosocial territories that are related to different discourses and languages of water rights legitimation. This refutes the conventional notions that see water rights as static and fixed elements of water systems or prescriptive tools for water governance. Water rights are dynamic sociomaterial and cultural-political relationships of inclusion and exclusion; and water rights legitimacy is constantly subject to review, assessment and revaluation within a vibrant network of social relationships. Therefore, to understand the underlying forces of government interventions or community struggles over water it is necessary to study the socio-political networks and "hydrosocial territories" in which water rights are legitimated or de-legitimated.

\footnotetext{
${ }^{5}$ The relation between a communal territory and resources is complex. An example of this complexity is the claim of informal irrigators along a big irrigation canal in the desert coast of Peru, who claimed they were entitled to pump water from the canal because they were originally from the highlands, some hundred kilometers upstream from the canal intake, where the water in the canal originates (Guimac, 2010).
} 


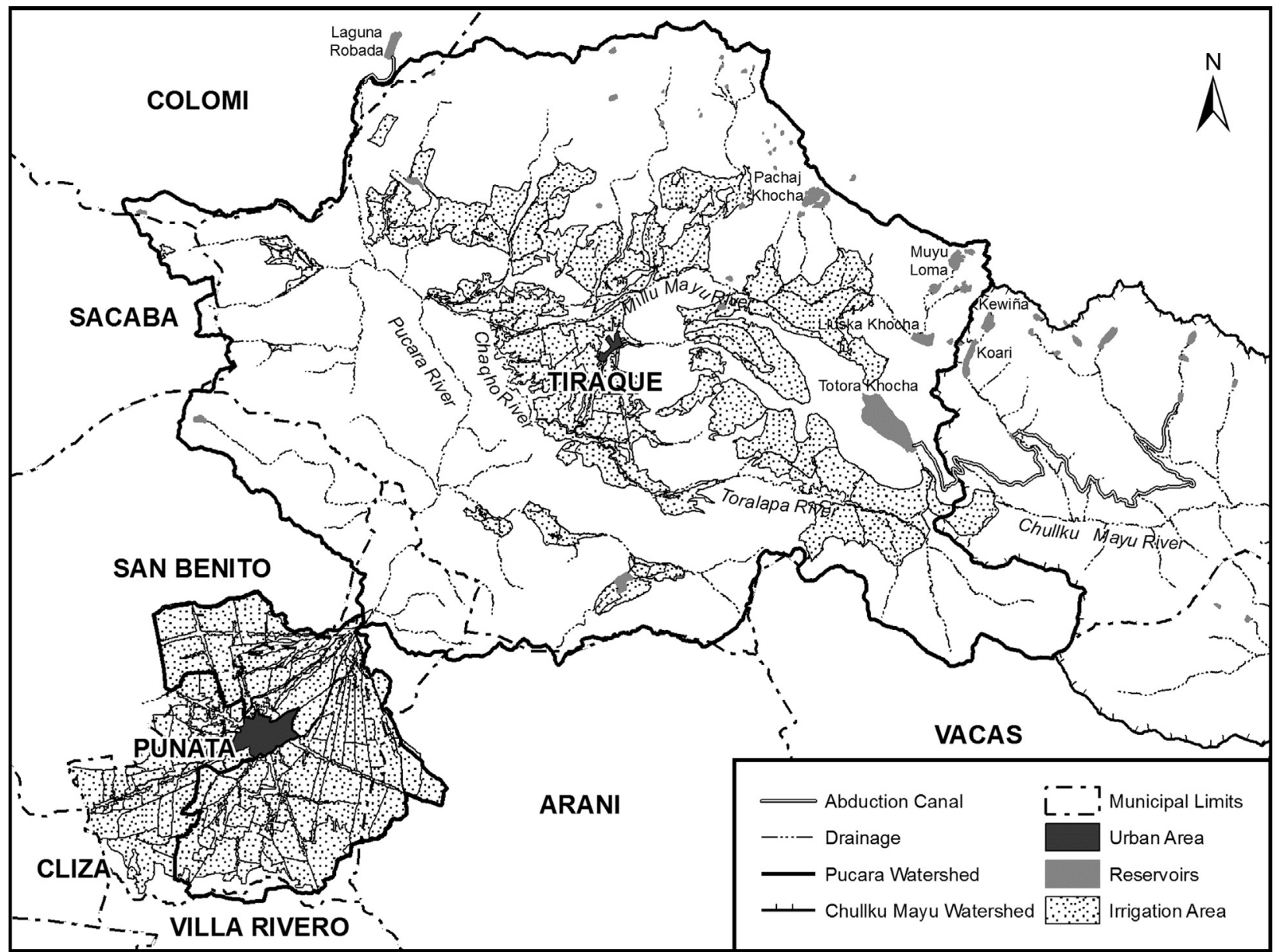

Fig. 1. The Pucara watershed.

Source: own elaboration.

\section{Study area description and methods}

The Pucara watershed is situated in the Upper Valley in the department of Cochabamba, in central Bolivia. It extends from the high, rugged mountains of Tiraque (up to $4650 \mathrm{~m}$ altitude) to the Punata Valley $(2800 \mathrm{~m}$ altitude). The Pucara watershed (Fig. 1) includes a catchment area and a discharge zone (bounded by the irrigation zone in the valley), with a total area of $482 \mathrm{~km}^{2}$. Administratively, the watershed is part of six municipalities (Tiraque, Punata, Arani, Colomi, Sacaba and San Benito). The Tiraque and Punata municipalities comprise $90 \%$ of the total watershed area and concentrate over $95 \%$ of its total population. The rural population is organized in rural communities, whereas the urban population is concentrated in the two main population centers: Punata and Tiraque.

The livelihoods of most people in the watershed are based on agriculture, and considering the shortage of rainwater, access to irrigation water is highly important for peasant communities. In this respect, the two municipalities differ notably. In the Tiraque municipality there is a relatively ample availability of water sources but lesser aptitude for agricultural production. This contrasts with the shortage of water sources but higher aptitude for irrigated agriculture in the Punata Valley. The Tiraque region is mostly mountainous and rugged, with thin, poor topsoil and a frigid $\left(10.2-13.6^{\circ} \mathrm{C}\right)$ and humid $(500-800 \mathrm{~mm}$ / year) climate. Agricultural production is limited to growing cold-hardy crops like potatoes, fava beans and grains. Historically more intensive production was restricted to the flatter areas of the alluvial fan near Tiraque village, whereas in the highland communities only small plots with food crops for self-consumption were grown. By contrast, the
Punata region is a flat alluvial fan, with deep, fertile topsoil and a temperate $\left(11.3-17.2^{\circ} \mathrm{C}\right)$ and dry $(300-400 \mathrm{~mm} /$ year) climate; enabling to grow a diversity of crops, such as corn, vegetables, peaches and others, under the condition of having access to irrigation water. Because of its own limited water availability, Punata's agricultural production has historically been highly dependent on water sources from Tiraque.

In the Pucara watershed, irrigation is by far the most important water use sector, consuming around $80 \%$ of the available resources (16-20\% domestic and 0-4\% industrial use). Thus, irrigation development is determinant in the configuration of hydrosocial territories. The present area under irrigation covers about 14,300 ha $(30 \%$ of the watershed's area), with 10,100 ha in Tiraque and 4200 ha in Punata. In Tiraque, a total of 21 communal irrigation systems were identified, with 12 systems using water from reservoirs, seven from springs and two from rivers (Cáceres, 2009). In Punata, a total of 74 community irrigation systems were identified, 66 systems tapping underground water using wells, four from rivers, three from reservoirs and one using treated waste water (Delgadillo and Lazarte, 2007; Saldías et al., 2012). Many families have water rights in more than one irrigation system and access water from more than one source.

Despite increasing extraction of underground water (in Punata), reservoirs are the main water source for irrigation and an important focus for government intervention. The importance of the reservoirs is due to the relative short rainy season (four months) and the rapidly declining flows in the rivers. Reservoir water is crucially important for more intensive and secure agricultural production. The fourteen reservoirs identified in the watershed store around $18.15 \mathrm{hm}^{3} /$ year, with 
three reservoirs receiving water transferred from neighboring watersheds. Eleven reservoirs are controlled by the Tiraque communities, two by Punata and one shared by the two regions.

The Pucara watershed is the result of historical conflict-ridden struggles and negotiations to control the watershed's water, among Punata and Tiraque (e.g., Gandarillas et al., 1994; Gerbrandy and Hoogendam, 2002; Rocha et al., 2015). Punata communities, taking advantage of their better biophysical conditions for irrigated agriculture, and their better political and socio-economic relations, were long preferred by Bolivian government investment in irrigation, besides the Tiraque communities' resistance.

The empirical data on the past water endeavors were collected through intensive fieldwork in 2009-2010, with follow-up visits throughout the years 2011-2018. Three main data collection methods were applied: review of published and unpublished documents, semistructured interviews and participant observations. The document review included the study of scientific literature, irrigation project documents and research reports. This resulted in the construction of a timeline of irrigation development actions in the watershed. In addition, a Geographic Information System (GIS) was established based on maps of irrigation systems and the systematization of information in three levels: water sources, hydraulic infrastructure and irrigation zone.

Three types of semi-structured interviews were conducted with key informants in the watershed. In the first round, four leaders of the irrigation users' associations in Tiraque and four in Punata were interviewed. These informants were selected according to the period of leadership. The interviews focused on the historical process of water control in the watershed; and how users gained and reproduced their water rights. The second type of interview was conducted with specific key actors involved in irrigation systems development in the watershed. Finally, 28 informants were interviewed: two informants (1 leader and 1 irrigator) for each irrigation system selected: six irrigation systems in Punata ( 3 reservoirs, 1 river and 2 underground water) and eight irrigation systems in Tiraque (6 reservoirs, 1 river and 1 spring). The interviews focused on the system-specific historical process of hydrosocial territorial configuration and how users gained, reproduced and defended their individual and collective water rights. The third type of interview was conducted with government officials and consultants involved in some irrigation development action in the watershed. Two former technicians who worked at the Inter Valley Irrigation Program (PRIV) and two consultants of specific irrigation projects were interviewed to examine the process of design and construction of irrigation systems in the watershed and the problems faced in the process.

Finally, several meetings of irrigation users' associations in Tiraque and Punata were observed (July-September 2009). In these meetings, notes were taken about the positions, discourses and discussions regarding the new proposals for irrigation projects. The same was done in 2017, through participation in four meetings between the Tiraque association and the highland communities about the future water rights of some highland reservoirs, as well as 3 meetings of the highland communities only.

\section{Irrigation development in the Pucara watershed}

The irrigation development process in the Pucara watershed is a clear example of the construction and reconstruction of different overlapping hydrosocial territories. The analysis of this (re)construction process shows that different user groups employ conflicting languages to legitimize water rights' claims and that the influence of these different languages over the water use and distribution outcomes changes over time. To understand this more clearly, the watershed's development process was divided into three periods, according to changes in most pro-active actor groups and their strategic actions to pursue new irrigation investments, and shifts in legitimation of water rights claims.

\subsection{From the hacienda to community control over irrigation water} (1950-1978)

Before the 1953 Bolivian Agrarian Reform, land and water in the Pucara watershed were mainly controlled by hacienda-owners, most of them descendants of Spaniards. Haciendas were cultivated by indigenous colonos, who worked the hacienda land in exchange for food and shelter. A limited number of indigenous and mestizo families, known as piqueros, owned small pieces of land outside the haciendas' dominion.

To solve water scarcity for agricultural production, the Punata and Tiraque hacienda landowners used colonos' labor force to build intakes and canals to conduct water from nearby rivers to their land. Since construction was usually organized by several hacienda owners, irrigation turns were set up for the distribution of the water. The right to use irrigation water was restricted to those landowners who participated in building the hydraulic infrastructure, which was a typical case of "hydraulic property creation": building collective and individual rights relationships through investments to construct hydraulic infrastructure (monetary and labor).

In view of the variability and unpredictability of river flows, landowners later chose to dam up natural lakes in the upper watershed, to store water in the rainy season and irrigate their fields in the dry season. The first reservoir, Laguna Robada, was constructed in 1929 by four Punata landowners on land of one of them, located in the higher part of Aguirre, over $20 \mathrm{~km}$ away from the Punata irrigation zone. Around 1950, Tiraque landowners built the Pachaj Khocha and Ovejería Khocha reservoirs. Since the reservoirs were situated far away from the irrigation zones, building and managing them required distant territorial control, which was possible since the highland areas were part of one or more haciendas. As in the river intake systems, the right to use water from the reservoirs was restricted to the landowners who took part in constructing the dam.

In this period, the legitimacy of landowners' claims to water was based on hydraulic property created in the construction of hydraulic infrastructure. However, the hydrosocial territories configured by landowners were re-ordered by the 1953 Agrarian reform, which terminated large landholding and the control of water by hacienda owners. The landowners were expelled and hacienda's land and water rights were distributed among the colonos who had worked that land. The indigenous peasants were organized in rural communities. The land of each hacienda was divided among one or more rural communities with clear territorial delimitations. These communities also claimed the right to control the water sources and the hydraulic infrastructure of the former haciendas, even when these sources were located outside the community's territory. In this way, rural communities re-ordered the hydrosocial territories that landowners had set up, enrolling large groups of new users, who had to establish new norms and ways to establish the collective action necessary for managing and using irrigation water. For example, the Ovejería Khocha reservoir was granted to four communities near the reservoir and Pachaj Khocha reservoir to 14 communities in the Tiraque fan. Laguna Robada was taken over by four communities in the Punata fan. Similarly, water taken directly from rivers came under the control of the rural communities conformed on the land of the former haciendas.

After a short period of decline in agricultural production, peasant families intensified land use and expanded the area under cultivation, increasing their demand for irrigation water, which came under further pressure when former piqueros (formerly free peasants) started to demand irrigation water as well. To increase water supply for their crops, Tiraque and Punata peasant communities joined efforts to improve the storage capacity of existing reservoirs and construct new ones. In this process, the argument that economic and labor investments in hydraulic infrastructure creates hydraulic property rights over water was the principal language to sustain claims for both collective and individual water rights. 
Table 1

Summary of actions by peasant communities to increase control over water of the Pucara watershed in the 1960-1978 period.

Source: Based on information from Gandarillas et al. (1994) and Gerbrandy (1991).

\begin{tabular}{|c|c|c|c|}
\hline Year & Reservoir & Actions & Beneficiaries \\
\hline \multirow[t]{2}{*}{1960} & Pachaj Khocha & Improving the dam & 14 Tiraque communities \\
\hline & Koari & Damming the natural lake & 1 Tiraque community \\
\hline 1964-1965 & Ovejería Khocha & Improving the dam $\left(0.8 \mathrm{hm}^{3}\right)$ & 9 Tiraque communities, supported by the Ministry of Public Works \\
\hline 1965 & Lluska Khocha and Muyu Loma & Damming 2 natural lakes & 12 Punata communities \\
\hline 1965-1966 & Pachaj Khocha & Improving the dam $\left(1.5 \mathrm{hm}^{3}\right)$ & 14 Tiraque communities, supported by the Ministry of Public Works \\
\hline $1968-1969$ & Lluska Khocha & Improving the dam & 12 Punata communities, supported by SNDC ${ }^{\mathrm{a}}$ \\
\hline 1973-1975 & Muyu Loma & Improving the dam $\left(1 \mathrm{hm}^{3}\right)$ & 12 Punata communities, supported by SNDC \\
\hline $1975-1978$ & Laguna Robada & Reconstructing the dam $\left(1.2 \mathrm{hm}^{3}\right)$ & 10 Punata communities, supported by SNDC \\
\hline
\end{tabular}

a SNDC: National Community Development Service (An autonomous decentralized government agency).

Table 1 lists the main actions taken by peasant communities in this period. Although initial actions were taken by communities themselves, the complexity and cost of building larger dams required the involvement of governmental entities to provide technical and financial support for construction. This government involvement, at the same time, reinforced the dominance of the hydraulic property language, legitimizing the claims over highland reservoir water for valley communities through the construction and rehabilitation of hydraulic works. In the construction processes, government contracted engineers consistently denied the highland (upstream) communities claims over water, since according to project documents the specific infrastructure was meant for both Tiraque and Punata valley communities. Thus, valley peasant communities in both Tiraque and Punata used the irrigation projects to consolidate and expand their hydrosocial territories, by creating hydraulic property regimes related to these water sources and reinforce its legitimizing language.

The expansion of the hydrosocial territories included, on the one hand, new water sources, and on the other new users and irrigated land. New beneficiaries were incorporated to help cover the labor demanded for infrastructure construction and to comply government requirements. Such was the case in the rehabilitation of the Ovejería Khocha reservoir in 1964. The Ministry of Public Works, that financed the project and provided technical support, requested a large number of project beneficiaries to justify public investment. Therefore, the four originally right-holding communities decided to include five more communities as project beneficiaries.

In the struggle to gain access to new water sources (all of them located in the upper part of the Tiraque region), the historical rivalry between Tiraque and Punata played an important role, and was a first indication of the shift in the territorial balance. According to Barnes and Torrico (1971), there has been a long-standing political and socioeconomic differentiation between Tiraque and Punata. The Punata vallunos (valley dwellers) historically had access to better education, markets and other services. By contrast, the Tiraque peasants had much less access to education and other services, relegating them to a lower socio-economic standing. However, in the strive for more water, Tiraque communities took advantage of their strategic position near the water sources to somehow level the playing field. For Punata peasants it was more difficult to gain and hold control over the water sources in the Tiraque territory, but still, through political influence were able to do so. A typical case was the participation of Punata peasants in the improvement of the Ovejería Khocha reservoir. Initially 50 Punata peasants participated in project works, attempting to acquire water rights to the reservoir (Reque, 1998). When they tried to play a leading role in the project, taking advantage of their higher educational level, the original rights-holders from Tiraque perceived the risk of losing control over their reservoir and excluded them from the project. The Punata peasants reacted violently and demanded rights to the reservoir water because of the work already done (hydraulic property). The conflict required the President of Bolivia, René Barrientos, to intervene. He persuaded the Punata peasants to withdraw from the joint project in exchange for an exclusive Punata one. Based on this agreement, peasants from 12 Punata communities dammed the Lluska Khocha and Muyu Loma reservoirs in the upper basin, getting the farmers in Tiraque to recognize their hydraulic property rights to these sources.

In sum, in the late 1970s Tiraque and Punata communities managed to consolidate their hydrosocial territories in the Pucara watershed and to manage them through overall acknowledged languages of water rights legitimation based on hydraulic property regimes. Many suffered from the fact that water sources were mostly situated outside their community boundaries. As stated above, political (even Presidential) pressure helped Punata peasants to get access to new reservoir sites. To gain local permission and maintain control over the water source and the hydraulic works, the Punata communities in charge of the Lluska Khocha - Muyu Loma reservoirs included users from the two Tiraque highland communities in which the dam and transfer canal are located. Similarly, Punata communities' Laguna Robada users included beneficiaries from the community in Aguirre where the reservoir is located.

As a result of these interventions, Tiraque valley communities got control over the water from the Millu Mayu and Toralapa rivers, plus four reservoirs, while Punata communities got control over the flow of the Pucara River and three reservoirs, with shared use with highland communities. Fig. 2 schematically shows the hydrosocial territories configured in the watershed, comprising the seven reservoirs constructed as of late 1978. The hydrosocial territories configured by Punata and Tiraque valley peasants extended to the upper watersheds. Their collective and individual water rights' legitimacy were mainly based on the hydraulic property created by capital and labor investments in the construction of hydraulic infrastructure. Only peasants who participated in construction works and had fulfilled their contributions, earned water rights and became partners in the irrigation system. However, the struggles between Tiraque and Punata communities to control the water sources of the upper watershed (Tiraque territory), were a first indication of the gradual shift to more territorial oriented claims over water rights.

\subsection{Government planned re-ordering of hydrosocial territories (1978-1995)}

By the late 1970s communities from the Punata and Tiraque valleys pressed for greater support from the Bolivian Government to increase irrigation water supply. To attend the potential of the Pucara watershed for irrigated agriculture, in 1978 the Altiplano Valleys Irrigation Program (PRAV) was established. This Program was aimed to increase water availability and modernize and re-order the peasant irrigation systems in the Pucara watershed, following economic and efficiency guidelines for irrigation. In their proposals, the designers considered the Pucara watershed as a mere physical-natural space, in which they could prescribe new governance principles, production plans and water distribution schedules. However, the rural communities fiercely defended their historically constituted water rights and hydrosocial territories, forcing diverse changes in the intervention proposals 


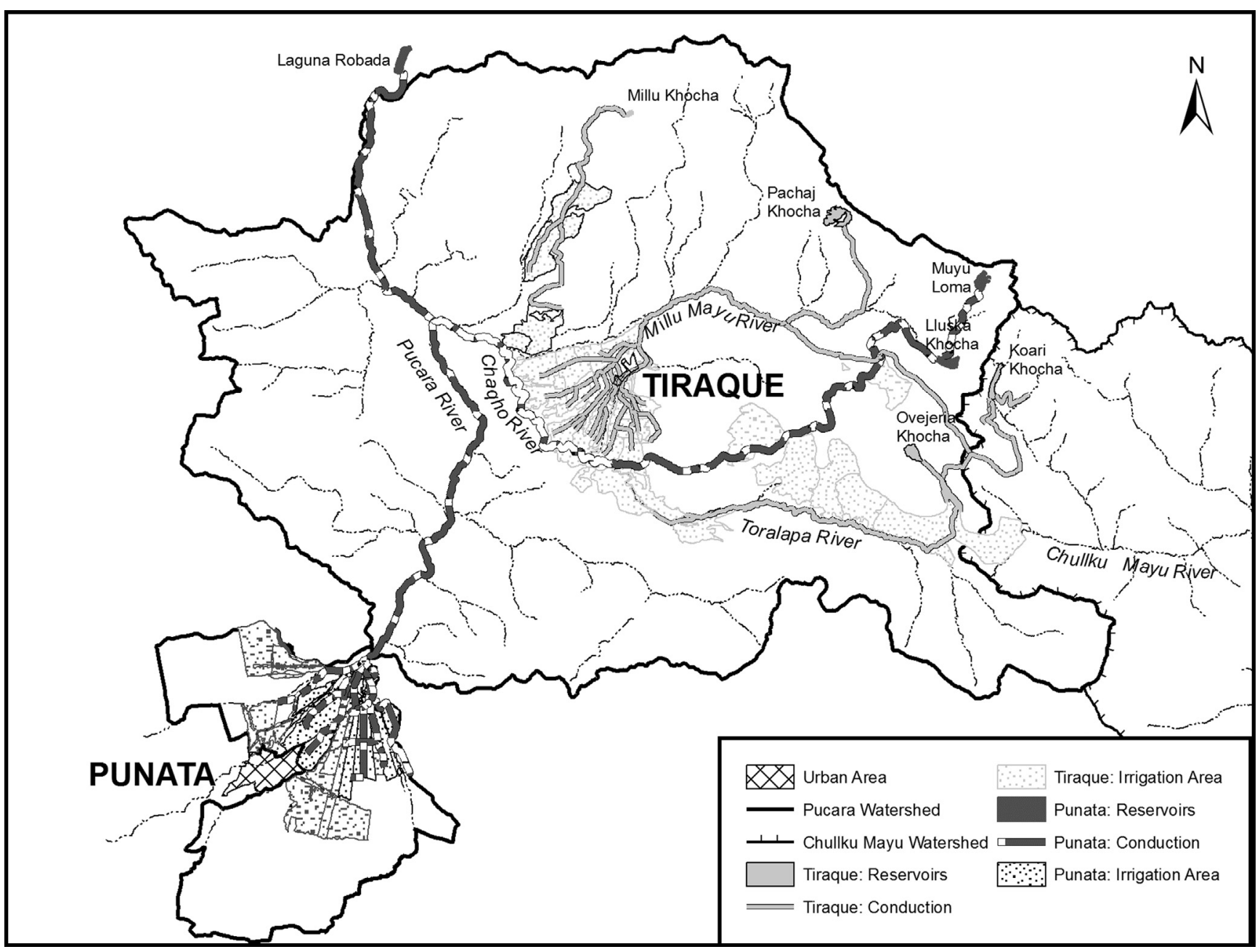

Fig. 2. Hydrosocial territories formed around the reservoirs by late 1978 in the Pucara watershed. Source: own elaboration.

(Gandarillas et al., 1994; Gerbrandy and Hoogendam, 2002; Rocha et al., 2015).

Between 1979 and 1991, PRAV implemented four projects (Table 2): one for Tiraque (Tiraque Project), two for Punata (Laguna Robada Project and Punata Phase I Project) and one shared one (Tiraque-Punata Project / Punata Phase II Project). The first three projects were oriented towards expanding existing reservoirs and improving the conduction and distribution networks. Although peasant communities demanded these projects, they faced diverse problems related to planned infrastructure and rules for water allocation, due to disagreements between technicians and communities about the legitimacy of claims for water use rights. PRAV technicians thought that, since public funds were being invested, the water supplied by the projects was a public asset that could be (re)allocated equally to all peasants, whether they had prior property right or not (Gerbrandy and Hoogendam, 2002). This proposal was rejected by the peasant water rights-holders, for whom water use rights were the result of former investments in hydraulic property creation. Following fierce discussions, in Punata it was decided that no new users could be included as beneficiaries, restricting labor contributions and consequent allocation of water rights to farmers with existing rights. By contrast, in Tiraque it was decided to include new users and water rights were allocated according to capital and labor contributions in constructing the new infrastructure.

The fourth project, originally named "Punata Phase II Project",

Table 2

Irrigation projects implemented by PRAV in the Pucara watershed.

Source: Based on Salzgitter Colsult GmbH (1991).

\begin{tabular}{|c|c|c|c|}
\hline Year & Project & Actions & Beneficiaries \\
\hline $\begin{array}{r}1979-1981 \\
1984-1985\end{array}$ & Tiraque Project & $\begin{array}{l}\text { Improving inter-connected reservoirs Koari Khocha }\left(2 \mathrm{hm}^{3}\right) \text { and Khewiña Khocha } \\
\left(1.5 \mathrm{hm}^{3}\right) \text {; conduction and distribution infrastructure }\end{array}$ & 20 Tiraque communities \\
\hline 1983-1985 & Laguna Robada Project & Improving Laguna Robada reservoir $\left(2.2 \mathrm{hm}^{3}\right)$ & $\begin{array}{l}10 \text { Punata communities } \\
+1 \text { community in Aguirre }\end{array}$ \\
\hline 1985-1988 & Punata Phase I Project & $\begin{array}{l}\text { Improving inter-connected reservoirs Lluska Khocha }\left(1.25 \mathrm{hm}^{3}\right) \text { and Muyu Loma }\left(1 \mathrm{hm}^{3}\right) \text {; } \\
\text { conduction and distribution infrastructure }\end{array}$ & $\begin{array}{l}12 \text { Punata communities } \\
+2 \text { Tiraque highland } \\
\text { communities }\end{array}$ \\
\hline 1988-1991 & $\begin{array}{l}\text { Tiraque-Punata Project (Punata } \\
\text { Phase II Project) }\end{array}$ & $\begin{array}{l}\text { Constructing Totora Khocha reservoir }\left(22 \mathrm{hm}^{3}\right) \text {; transfer from neighboring Chullku Mayu } \\
\text { basin; expanding distribution infrastructure }\end{array}$ & $\begin{array}{l}52 \text { Punata communities } \\
33 \text { Tiraque communities }\end{array}$ \\
\hline
\end{tabular}


aimed to drastically reorganize historically constituted water rights and hydrosocial territories. Its main component was the construction of a large new reservoir, Totora Khocha, with a $22 \mathrm{hm}^{3}$ capacity, to be built on the site of the existing Ovejería Khocha reservoir $\left(0.8 \mathrm{hm}^{3}\right)$ and aimed to provide irrigation water to the productive land of the Punata valley. The new reservoir would store water transferred from the neighboring Chullcu Mayu watershed. Its water would form, together with the flows from the other three Punata reservoirs (Laguna Robada, Muyu Loma Lluska Khocha), an integrated irrigation system that would operate with a single, continuous water flow, determined to cover theoretically calculated crop water requirements. The proposal was based on technical and economic criteria, aiming at efficient irrigation of fertile farmlands to ensure high profits for rural families and justify the investment. The water was proposed to be for the Punata region only, since designers' calculations showed that water requirements for the irrigable land in Tiraque were already covered by the available water.

Tiraque communities objected to the idea that the Totora Khocha reservoir would only benefit Punata communities. First, the nine Tiraque communities that held the Ovejería Khocha reservoir claimed their hydraulic property rights over the existing reservoir. After tough negotiations, it was agreed to recognize and respect the original hydraulic property rights, entailing the right for these communities to manage and autonomously use the $0.8 \mathrm{hm}^{3} /$ year volume stored in the new Totora Khocha reservoir. Second, the 33 communities located in the Tiraque valley questioned the invasion of Punata control in Tiraque territory and collectively claimed their socio-territorial rights to the water of future reservoir. Under the slogan "the water is ours, because it is in our territory", the Tiraque communities claimed priority usage rights from Totora Khocha. Although including Tiraque communities in the project would reduce the planned water supply for Punata and jeopardize its technical and economic feasibility, PRAV technicians realized that the project could not be implemented without their consent, since Tiraque communities threatened to impede construction works through road blocks and marches. They thus proposed to include the Tiraque communities in the project and proposed to share the new reservoir water. After harsh negotiations, in June 1990 a final agreement was signed, establishing shared control and use of Totora Khocha by Tiraque and Punata, respecting the former $0.8 \mathrm{hm}^{3}$ Ovejería volume and distributing the additionally stored volume on a proportional basis according the total number of shares (gained water rights by users) in the reservoir for each zone: $60 \%$ for Punata and $40 \%$ for Tiraque.

The story of the PRAV intervention shows that in origin the ideas to construct new reservoirs proposed implicit changes in the existing irrigation systems (hydrosocial territories), ignoring existing water rights. In response, Tiraque and Punata communities contested the attempt to enforce a new language of water rights legitimation and claimed the legitimacy of their own languages. Their arguments were based, on the one hand, on hydraulic property creation and, on the other, on territorial claims over the water sources exploited. As a result, PRAV technicians and peasant communities from both Punata and Tiraque negotiated the redesign of the water allocation principles. The evaluation of this contented process led to the creation of a new school of irrigation practice in Bolivia, based on the recognition of a longstanding Andean highlands irrigation tradition, profoundly informed by hydraulic property regimes (Gandarillas et al., 1994; Gerbrandy and Hoogendam, 1998).

The PRAV projects changed the hydrosocial territories of Punata and Tiraque communities. Fig. 3 shows how, by in the middle of the 1990s, Tiraque valley communities controlled at least 10 reservoirs, while Punata communities controlled only four, shared with highland communities as strategic partners. Although the Punata communities got at least partial control over a new water source, the Tiraque communities clearly managed to achieve signs of socio-territorial control over the water sources in the upper watershed.

\subsection{Further territorializing water (1995-2017)}

In the last two decades, many new investments in irrigation works have been done in both Punata and Tiraque municipalities. However, the spatial character and dimension of these investments have changed importantly, as well the languages of water rights legitimation, through the increase of socio-territorial control over the water sources in the upper watershed. This is mainly due to the process of administrative decentralization or municipalization (Law of Popular Participation) that started in 1995, and the empowerment of indigenous/peasant communities promoted by the Evo Morales Government since 2006. In this process, planning and investment responsibilities were delegated to the municipal level, introducing systems of participatory planning based on community demands and municipal investment in rural and urban communities proportional to population numbers. Because of the participative planning, the municipalization process visualized the formerly 'hidden' rural communities, which in the study case were the poorer and more remote highland communities from Tiraque, in which main water sources originate and all reservoirs are situated. These communities demanded to invest their share of public funding in health, education and irrigation infrastructure mainly. In contrast, before the municipalization process, rural populations could only obtain state funding through departmental government offices, which were mainly mobilized through political relationships. This was only feasible for rural groups with departmental ties, such as the more integrated Punata and Tiraque valley peasantry, as witnessed in the before mentioned PRAV projects.

Other important characteristics of the municipalization process were the clearer definition of municipal boundaries, the expansion of the mayor's responsibility over the whole municipal territory (before 1995 the mayor's office dealt with urban issues only) and the obligation to invest municipal means within its territorial boundaries only. In a few years, this led to the strengthening of the territorial argument underlying resource claims; for all kinds of resources (wood, cement, gravel, mining, etc.), but for water most strongly, considering the vital role of water for people's livelihoods (drinking and irrigation) in the municipalities. This process was deepened by Evo Morales Government (2006), which institutionalized and consolidated the local and regional governance on the basis of indigenous/peasant communities. Through a new Constitution (2009), the Bolivian government restructured democratic representation and governance around indigenous autonomy and communitarian values, empowering indigenous/peasant communities and giving them the right to make decisions about their territories and their resources (Morales, 2011).

As a result, over two decades, claiming territorial rights over the water resources located in their territories, highland communities from Tiraque implemented numerous irrigation projects, gaining control over ten new small reservoirs $\left(0.05-0.90 \mathrm{hm}^{3}\right)$. Through these investments practically all surface water flows and sources in the Pucara watershed became in use, part of the hydrosocial territory controlled by one or various peasant communities. This proliferation of irrigation systems resulted in the virtual closure of the Pucara watershed (e.g., Molle, 2003), meaning that there is no more 'free water' flowing in the watershed. This forced all communities to reorient their actions towards alternative sources within their municipal boundaries or towards investments aimed at transferring water from other watersheds.

Water transfer projects would re-open the Pucara watershed by importing 'new water'. Since the 1990s, one of the possible options was the Yungas de Vandiola transfer project; capturing water from the mountain range north of Tiraque, to be released in the upper Pucara watershed and to be used in the downstream areas (see Rocha López et al., 2019). These waters originate in the highland communities, but were proposed to just pass through them to irrigate land in the Tiraque and Punata valley communities. But to defend the use of these waters, in 2008, the highland communities organized themselves at the local level in the Highland Association (Asociación de Alturas) and at the 


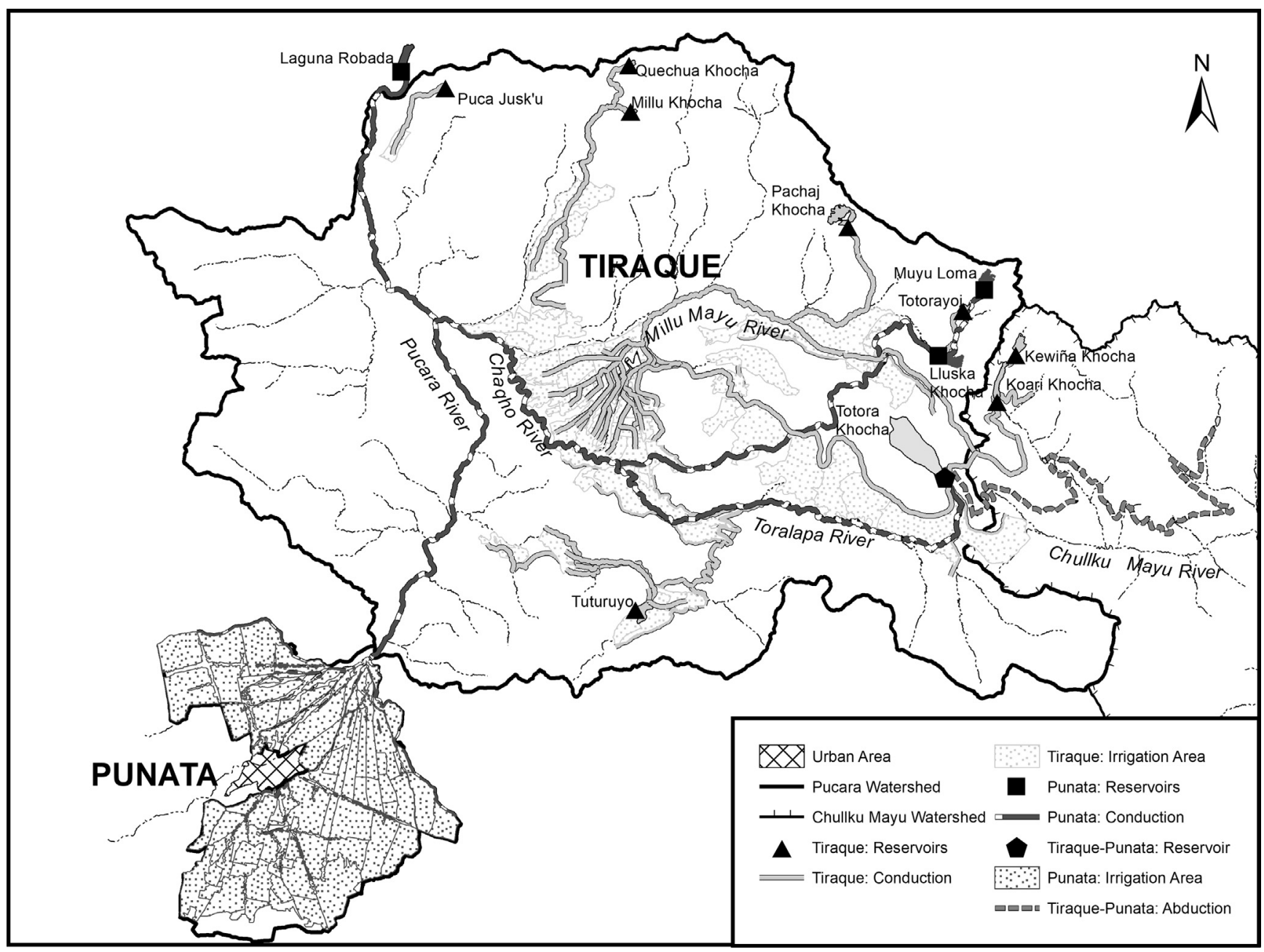

Fig. 3. Hydrosocial territories formed around the reservoirs by late 1991 in the Pucara watershed.

Source: own elaboration.

regional level in the Cochabamba Indigenous Agricultural Irrigators Federation (FRIAC, Federación de Regantes Indígenas Agropecuarios de Cochabamba). Both organizations were a clear expression of cultural (quechua), socioeconomic and geographical belonging by the indigenous, highland, poorer and less formally-educated communities, that did not feel represented by the existing irrigators organizations and were denied in all earlier investments in water projects even though taking place in their territories (Callejo et al., 2012). The creation of these two organizations was as a vivid expression of their territorial claim over water and the strategic need to collectively defend it.

In 2011, when the feasibility study for the Yungas de Vandiola transfer project was eventually implemented, the official objective was still to increase the very low water volume of the Totora Khocha reservoir, since it fell behind original expectations. ${ }^{6}$ In official documents it was stated that the additional volume was to increment water availability for the Punata and Tiraque valley communities only. As could be expected, the highland communities from Tiraque opposed this idea strongly, claiming territorial rights over the transfer water and demanding to solve their water scarcity issues first. To underscore their position, they destroyed hydrometric instruments and blocked the (only) road to the watersheds at stake. As a result of their protests, the project idea was eventually abandoned, as was the naïve idea that the project was situated in no-one's land. In 2011, the highland

\footnotetext{
${ }^{6}$ From 1991 until 2008, Totora Khocha stored an average of $7.2 \mathrm{hm}^{3}$ per year; $33 \%$ of its' total capacity.
}

communities had already become highly visible as important actors for any future water transfer initiative.

Another interesting detail of the Yungas de Vandiola project was that it reopened the discussion between Tiraque and Punata valley communities about the proportions of water distributed from Totora Khocha reservoir. Taking advantage of the increasingly accepted discourse on territorial water rights, Tiraque communities re-negotiated the terms of the original distribution agreement to $50 \%$ for Tiraque and $50 \%$ for Punata, to be effective from the moment the Yungas de Vandiola transfer would begin to operate (Rocha López et al., 2019).

In 2013, Tiraque valley communities restarted the discussion on the water transfer project with the highlanders. This time, Punata beneficiaries were left out of the project. To create a project useful for both valley and highland communities from Tiraque, the idea of storing the transfer water in Totora Khocha reservoir was abandoned. Totora Khocha is situated at a lower level (3750 masl) than the highland communities (between 3800 and 4000 masl) and would thus be useless for them. Instead, eyes were set on the Pachaj Khocha reservoir, situated at 4000 masl, controlled by 14 Tiraque valley communities. It has an actual capacity of $1.5 \mathrm{hm}^{3}$ but may be extended to $3 \mathrm{hm}^{3}$ for storing the transfer water. In 2013, the Pachaj Khocha irrigators Committee signed a secret agreement with the Sankayani community, where the reservoir is situated, consenting on sharing the additional volume in halves. In this way, the actual Pachaj Khocha users would preserve and increase their hydraulic property rights and guarantee the legitimacy of these rights through a strategic association with the territory holders. 
When in 2016, public discussions about the Pachaj Khocha enlargement started (involving the mayor's office and departmental government) the other highland communities objected to the narrow territorial interpretation of one single community in the 2013 agreement and the exclusion of the other communities that were members of the Highland Association, while founded to collectively defend their natural resources. In August 2016 a new agreement was signed, stating that the future distribution of additional water would be $48 \%$ for the existing rights-holder valley communities and $52 \%$ for the highland territorial owners.

In the Punata region, the municipalization process and the closure of the Pucara watershed, left ground water as the only alternative for irrigation, being the only territorially secure water source. After first experiences since the mid-1970s, drilling increased enormously after 1995; groundwater became the foremost water source for Punata. In 2010, 205 wells were operating (113 for irrigation, 76 for domestic use, 11 for both irrigation and domestic use and five for industrial use), with a total annual extraction of $16.7 \mathrm{hm}^{3}$ (Mayta, 2012). Compared to the previous period, the number of wells had increased by $400 \%$, due to which the water table dropped significantly and ever deeper wells must be drilled to be effective.

Fig. 4 schematically shows the hydrosocial territories constituted by 2017, highlighting the increase of reservoirs in the Tiraque highlands and the proliferation of wells in Punata Valley. Compared with the previous period (Fig. 3) and because of territorial closure, Punata could not capture new water sources in the watershed. Instead, they lost influence in the upper watershed and were virtually excluded from future transfer projects. By contrast, Tiraque communities controlled ten new small reservoirs, consolidating the socio-territorial right over the water sources of the upper watershed. The winners of the shift in the water rights languages towards territorial claims are the highland communities, which because of their strategic location and organizational efforts, managed to get greater control over the water sources that originate in their communal territories. Their power resides in the impossibilities for others to construct any hydraulic works in their territory without their consent, because of the collective defense of their supra-communal space.

\section{Discussion and conclusions}

In this article, we have analyzed how peasant communities in the Bolivian Andean region pro-actively searched for new water sources for irrigation and molded the processes to re-order their hydrosocial territories through a diversity of actions. We used the recent concept of hydrosocial territories as a new theoretical "lens" to look at dynamically changing water rights frameworks. It enabled to see and understand how different actors, who conceptualize and imagine their territory in different ways, strategically deploy particular, corresponding water rights legitimation languages to reinforce their water claims and materialize their wished-for hydrosocial territory.

The irrigation development in the Pucara watershed shows how, as water became scarcer and water demands increased, peasant user

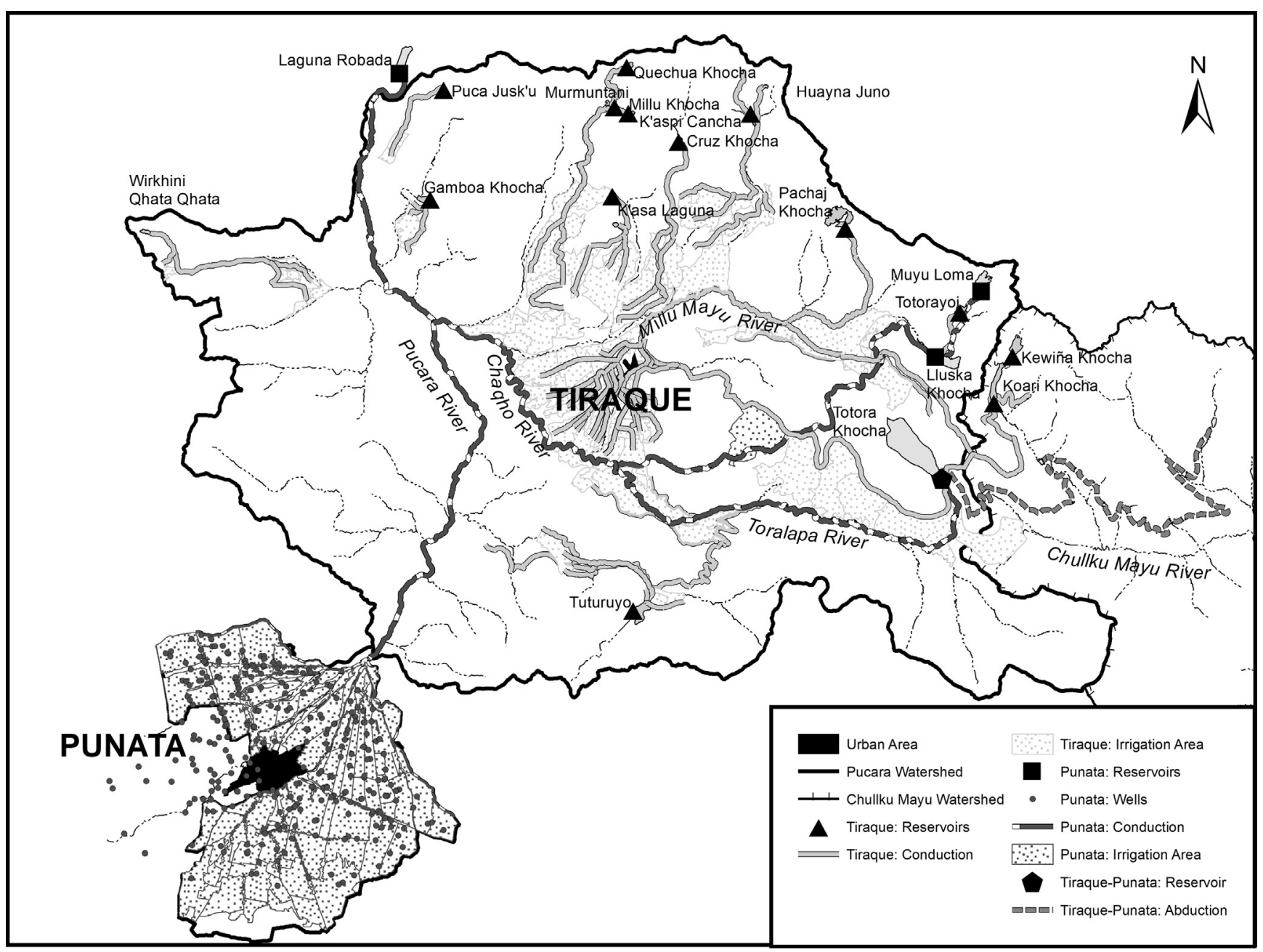

Fig. 4. Hydrosocial territories formed around the reservoirs by late 2010 in the Pucara watershed.

Source: own elaboration. 
collectives required extending their hydrosocial territories by constructing and improving hydraulic infrastructure to capture more water. Some of these actions (often supported by the Bolivian state through irrigation projects) were designed at the expense of affecting water rights and territories of other collectives, but enhanced under the umbrella of the right-giving argument of hydraulic property: those who invest in the construction of the hydraulic works needed, are entitled to use the transported water and govern the system.

Over time, affected peasant communities developed diverse strategic-political actions to defend and legitimate their claims to water rights. In this process, peasant communities and water user collectives managed to gradually change the dominant language of water rights legitimation, and used language that resonated with the changing discourse of the government after the election of president Morales. Along the three studied periods (1950-2017), the preponderant language of water rights legitimation changed from modes based on hydraulic property rights creation to modes stressing territory-based claims. The territorialization of water claims is intimately related to changes in national normative and policies, like the process of administrative decentralization (municipalization), and the empowerment of indigenous peasant communities. The process of municipalization of public planning and investment strengthened the spirit of territorialization, inducing to municipal demarcation of water projects and beneficiaries, and brought in municipal authority to defend territorial claims. In fact, in Tiraque a process of multi-scalar territorialization took place: all Tiraque communities against Punata communities, highland communities against valley communities and within the highland a single community against its neighbors. ${ }^{7}$

This historic development around water also reflects the changing power structures in the watershed, as expressed in specific patterns of access to water and dominant discourses about water control. The political and economic power excercised first by the landowners and then by the Bolivian government, allowed the Punata communities to expand their hydrosocial territories and control water sources upstream in the watershed. However, new attempts to expand Punata hydrosocial territories, following discourses of 'economic logic' and 'efficiency', were fiercely contested by Tiraque communities claiming socio-territorial rights over the water sources in the waterhed. Favoured by the administrative descentralization process, Tiraque communities positioned the socio-territorial discourse to defend and legitimate their claims over water rights. The favourable location of Tiraque communities (upstream) entailed being in a relatively better position whenever future plans for water development materialize in the watershed.

In this context, for peasant communities the languages of territorial rights legitimization include the right to take control and use of the resources within their territory (water, land, grazing lands, etc.) and the right to take decisions about them. The latter is especially true for the highland communities, which until recently, were socio-economically and culturally subordinated to the valley communities of both Tiraque and Punata, and thus neglected in external decision making about their territorial resources. Their current empowerment makes it impossible to deny them in future water projects and urges to reach consent about equitable distribution of future water benefits.

In this paper, we have shown the dynamic nature of water rights claims (and their acceptance) within and among key water governance actors, contesting prevailing notions of water rights frameworks that focused on static legal doctrines; age-old ("traditional") customary peasant and indigenous rights; or overwhelming market forces. The newly established (but continuously contested) languages for water

\footnotetext{
${ }^{7}$ For now, only the last contradiction (between a highland community and its highland neighbors) has been 'solved'. Highland communities feel empowered; their need for collective defense based on cultural, socio-economic and geographical belonging has enabled them to generate a new space for collective action within and among the highland communities.
}

rights legitimation in the Pucara watershed shifted from modes based on hydraulic property creation to territory-based modes, as a basis for defending claims to water. Contributing to the water rights literature, the approach deploys the concept of hydrosocial territories to analyze these strategic languages that legitimize and strengthen claims regarding water use rights. Hydrosocial territories are not merely biophysical, legal-administrative and political-geographical constructs but equally build on imaginaries, epistemologies and discourses that relate to specific values and languages of water rights legitimization, which dynamically take shape in moralized water technology and humanized nature.

\section{References}

Agnew, J., 1994. The territorial trap: the geographical assumptions of international relations theory. Rev. Int. Political Econ. 1 (1), 53-80.

Baletti, B., 2012. Ordenamento Territorial: neo-developmentalism and the struggle for territory in the lower Brazilian Amazon. J. Peasant Stud. 39 (2), 573-598.

Barnes, K., Torrico, J., 1971. Cambios socio-económicos en el Valle Alto de Cochabamba desde 1952: los pueblos provinciales de Cliza, Punata, Tiraque, Arani, Sacaba y Tarata. Estudios Andinos 2 (1), 141-171.

Bebbington, A., Humphreys Bebbington, D., Bury, J., 2010. Federating and defending: Water, territory and extraction in the Andes. In: Boelens, R., Getches, D., Guevara-Gil, A. (Eds.), Out of the Mainstream. Earthscan, London and Washington DC, pp. 307-327.

Beccar, L., Boelens, R., Hoogendam, P., 2002. Water rights and collective action in community irrigation. In: Boelens, R., Hoogendam, P. (Eds.), Water Rights and Empowerment. Van Gorcum, Assen, The Netherlands, pp. 1-19.

Benda-Beckmann, F.V., 2001. Legal pluralism and social justice in economic and political development. IDS Bull. 32 (1), 46-56.

Benda-Beckmann, F.V., 2007. Contestations over a life-giving force: Water rights and conflicts, with special reference to Indonesia. In: Boomgaard, P. (Ed.), A World of Water. Rain, Rivers and Seas in Southeast Asian Histories. KITLV Press, Leiden, pp. 259-277.

Benford, R.D., Snow, D.A., 2000. Framing processes and social movements: an overview and assessment. Ann. Rev. Sociol. 26 (1), 611-639.

Bleeker, S., Vos, J., 2019. Payment for ecosystem services in Limás watersheds: power and imaginaries in an urban-rural hydrosocial territory. Water International.

Boelens, R., 2015. Water, Power and Identity: The Cultural Politics of Water in the Andes. Routledge, Taylor \& Francis Group, London.

Boelens, R., Doornbos, B., 2001. The battlefield of water rights: rule making amidst conflicting normative frameworks in the Ecuadorian highlands. Human Organ. 60 (4), 343-355.

Boelens, R., Hoogesteger, J., Swyngedouw, E., Vos, J., Wester, P., 2016. Hydro-social territories: a political ecology perspective. Water Int. 41 (1), 1-14.

Boelens, R., Roth, D., Zwarteveen, M., 2005. Legal complexity in the analysis of water rights and water resources management. In: Roth, D., Boelens, R., Zwarteveen, M. (Eds.), Liquid Relations. Rutgers University Press, New Brunswick/NJ, London, pp. $1-20$.

Boelens, R., Seemann, M., 2014. Forced engagements. Water security and local rights formalization in Yanque, Colca Valley, Peru. Human Organ. 73 (1), 1-12.

Boelens, R., Vos, J., 2014. Legal pluralism, hydraulic property creation and sustainability: the materialized nature of water rights in user-managed systems. Curr. Opin. Environ. Sustain. 11, 55-62.

Bruns, B., Meinzen-Dick, R., 2005. Frameworks for water rights: an overview of institutional options. In: Bruns, B., Ringler, C., Meinzen-Dick, R. (Eds.), Water Rights Reform: Lessons for Institutional Design. International Food Policy Research Institute, Washington, DC, pp. 3-25.

Budds, J., Hinojosa, L., 2012. Restructuring and rescaling water governance in mining contexts: the co-production of waterscapes in Peru. Water Altern. 5 (1), 119-137.

Cáceres, W., 2009. Gestion de sistemas de riego cuenca hidrográfica Pucara. Centro AGUA UMSS, Cochabamba, pp. 68.

Callejo, I.D., Quiroz, F., Cossío, V., 2012. Dinámicas organizativas en torno al agua en la cuenca hidrosocial Pucara. In: Quiroz, F., Delgadillo, O., Durán, A. (Eds.), Aguas Arriba, Aguas Abajo. Luces y Sombras de la Gestión Integral de Recursos Hídricos. Plural Editores, Centro AGUA-UMSS, La Paz, Bolivia, pp. 185-228.

Castro, J.E., 2007. Poverty and citizenship: sociological perspectives on water services and public-private participation. Geoforum 38 (5), 756-771.

Cleaver, F., 2000. Moral ecological rationality, institutions and the management of common property resources. Dev. Change 31 (2), 361-383.

Coward, E.W., 1983. Property in action. Alternatives for Irrigation Investment. University of Khon Kaen, Khon Kaen, Thailand, pp. 28.

Coward, E.W., 1986. State and locality in asian irrigation development: the property factor. In: Nobe, K.C., Sampath, R.K. (Eds.), Irrigation Management in Developing Countries: Current Issues and Approaches. Westview Press, Boulder and London, pp. 491-508.

Delgadillo, O., Lazarte, N., 2007. Gestión de los sistemas de aprovechamiento de agua en el municipio de Punata. Centro AGUA - UMSS, Cochabamba, pp. 69-169.

Duarte-Abadía, B., Boelens, R., 2016. Disputes over territorial boundaries and diverging valuation languages: the Santurban hydrosocial highlands territory in Colombia Water Int. 41 (1), 15-36. 
Duarte-Abadía, B., Boelens, R., 2019. Colonizing rural waters. The politics of hydro-ter ritorial transformation in the Guadalhorce Valley, Málaga, Spain. Water International.

Duarte-Abadia, B., Boelens, R., Roa-Avendaño, T., 2015. Hydropower, encroachment and the re-patterning of hydrosocial territory: the case of Hidrosogamoso in Colombia. Human Organ. 74 (3), 243-254.

Elden, S., 2010. Land, terrain, territory. Prog. Hum. Geogr. 34 (6), 799-817.

Escobar, A., 2008. Territories of Difference: Place, Movements, Life, Redes. Duke University Press, Durham and London.

Gandarillas, H., Salazar, L., Sánchez, L., Sánchez, L.C., de Zutter, P., 1994. Dios da el Agua ¿Que Hacen los Proyectos? Manejo de Agua y Organización Campesina, Segunda ed ed. HISBOL-PRIV, La Paz, Bolivia.

Gearey, M., Jeffrey, P., 2006. Concepts of legitimacy within the context of adaptive water management strategies. Ecol. Econ. 60 (1), 129-137.

Gelles, P.H., 2000. Water and Power in Highland Peru. The Cultural Politics of Irrigation and Development. Rutgers University Press, New Brunswick, New Jersey and London.

Gerbrandy, G., 1991. Concepción Campesina de Gestión de Agua. Deutsche Gesellschaft Fur Technische Zusammnarbeit (GTZ) GmbH, Dordrecht, Holanda, pp. 57.

Gerbrandy, G., Hoogendam, P., 1998. Aguas y Acequias. Los Derechos al Agua y la Gestión Campesina. de Riego en los Andes Bolivianos. Plural Editores, La Paz, Bolivia.

Gerbrandy, G., Hoogendam, P., 2002. Materialising rights: hydraulic property in the extension and rehabilitation of two irrigation systems in Bolivia. In: Boelens, R., Hoogendam, P. (Eds.), Water Rights and Empowerment. Van Gorcum, Assen, The Netherlands, pp. 36-51.

Goldman, M., Narayan, D., 2019. Urban transformation through the analytic of water crisis: a study of Bangalore's hydrosocial regimes. Water International.

Guevara-Gil, A., Boelens, R., Getches, D., 2010. Conclusions: Water rights, power and identity. In: Boelens, R., Getches, D., Guevara-Gil, A. (Eds.), Out of the Mainstream. Earthscan, London and Washington, pp. 329-339.

Guimac, M., 2010. Los extractores del agua en las márgenes del nuevo canal Taymi. In: Vos, J. (Ed.), Riego Campesino en los Andes: Seguridad Hídrica y Seguridad Alimentaria en Ecuador, Perú y Bolivia. IEP, Lima, pp. 191-206.

Harris, L.M., Roa-García, M.C., 2013. Recent waves of water governance: constitutional reform and resistance to neoliberalization in Latin America (1990-2012). Geoforum 50, 20-30.

Hidalgo, J.P., Boelens, R., Vos, J., 2017. De-colonizing water. Dispossession, water insecurity, and indigenous claims for resources, authority, and territory. Water History 9 (1), 67-85.

Hidalgo-Bastidas, J.P., Boelens, R., Isch, E., 2018. Hydroterritorial configuration and confrontation: the Daule-Peripa multipurpose hydraulic scheme in coastal Ecuador. Latin Am. Res. Rev. 53 (3), 517-534.

Hodgson, S., 2004. Land and Water - The Rights Interface, FAO Legal Papers Online. Food and Agricultural Organisation of the United Nations (FAO), Rome, pp. 80.

Hommes, L., Boelens, R., 2017. Urbanizing rural waters: rural-urban water transfers and the reconfiguration of hydrosocial territories in Lima. Polit. Geogr. 57, 71-80.

Hommes, L., Boelens, R., 2018. From natural flow to 'working river': hydropower development, modernity and socio-territorial transformations in Lima's Rímac watershed. J. Historical Geogr. 62, 85-95.

Hommes, L., Boelens, R., Maat, H., 2016. Contested hydrosocial territories and disputed water governance: struggles and competing claims over the Ilisu Dam development in southeastern Turkey. Geoforum 71, 9-20.

Hoogendam, P., 2018. Hydrosocial territories in the context of diverse and changing ruralities: the case of Cochabamba's drinking water provision over time. Water International.

Hoogesteger, J., Boelens, R., Baud, M., 2016. Territorial pluralism: water users' multiscalar struggles against state ordering in Ecuador's highlands. Water Int. 41 (1), 91-106.

Hulshof, M., Vos, J., 2016. Diverging realities: how framing, values and water management are interwoven in the Albufera de Valencia wetland in Spain. Water Int. 41 (1), 107-124.

Hutchins, W.A., 1971. Water Rights Laws in the Nineteen Western States (Volume I). Natural Resources Economics Division, Economic Research Service US Department of Agriculture, Washington, pp. 650.

Jackson, S., 2018. Water and indigenous rights: mechanisms and pathways of recognition, representation, and redistribution. Wiley Interdisciplinary Rev: Water 5 (6), e1314.

Lynch, B.D., 2012. Vulnerabilities, competition and rights in a context of climate change toward equitable water governance in Peru' s Rio Santa Valley. Global Environ. Change 22 (2), 364-373.

Mancano, B., 2009. Territorio, teoria y politica. In: Lozano, F., Ferro, J.G. (Eds.), Las Configuraciones de los Territorios Rurales en el Siglo XXI. Editorial Pontificia Universidad Javeriana, Bogota, pp. 35-62.

Marks, D., 2019. Assembling the 2011 Thailand floods: protecting farmers and inundating high-value industrial estates in a fragmented hydro-social territory. Polit. Geogr. 68, $66-76$.

Martinez-Alier, J., 2009. Social metabolism, ecological distribution conflicts, and languages of valuation. Capitalism Nat Social. 20 (1), 58-87.

Mayta, A., 2012. Disponibilidad de agua subterranea en el Abanico de Punata. Centro AGUA - UMSS, Cochabamba, pp. 26-126.

Meehan, K., 2013. Disciplining de facto development: water theft and hydrosocial order in Tijuana. Environ. Plann. D: Soc. Space 31, 319-336.

Meinzen-Dick, R., Pradhan, R., 2005. Analyzing water rights, multiple uses, and intersectoral water transfers. In: Roth, D., Boelens, R., Zwarteveen, M. (Eds.), Liquid Relations. Contested Water Rights and Legal Complexity. Rutgers University Press, New Brunswick, New Jersey, London, pp. 237-253.

Ministerio del Agua, 2007. Plan Nacional de Desarrollo de Riego “...para vivir bien” 2007-
2011. Ministerio de Agua - Viceministerio de Riego - Servicio Nacional de Riego, La Paz, Bolivia, p. 71.

Molle, F., 2003. Development Trajectories of River Basins: A Conceptual Framework. International Water Management Institute, Colombo, Sri Lanka.

Morales, W.Q., 2011. From revolution to revolution: Bolivia's national revolution and the "re-founding" revolution of Evo Morales. Latin Am. 131-145.

Orlove, B., Caton, S.C., 2010. Water Sustainability: anthropological approaches and prospects. Ann. Rev. Anthropol. 39, 401-415.

Paerregaard, K., 2013. Governing water in the andean community of Cabanaconde, Peru. Mountain Res. Dev. 33 (3), 207-214.

Perreault, T., 2008. Custom and contradiction: rural water governance and the politics of usos y costumbres in Bolivia's irrigators' movement. Ann. Assoc. Am. Geogr. 98 (4), 834-854.

Pfaffenberger, B., 1988. Fetishised objects and humanised nature: towards an anthropology of technology. Man 23 (2), 236-252.

Rasmussen, M.B., 2015. Andean Waterways: Resource Politics in Highland Peru. University of Washington Press, Washington.

Rawson, A., Mansfield, B., 2018. Producing juridical knowledge: "rights of nature" or the naturalization of rights? Environ. Plann. E: Nat. Space 1 (1-2), 99-119.

Reque, D., 1998. Influencia del proyecto de riego inter-valles en la gestión de riego del sistema Totora Khocha Antiguos. Universidad Mayor de San Simón, Cochabamba, Bolivia, pp. 138.

Ringler, C., Rosegrant, M., Paisner, M., 2000. Irrigation and Water Resources in Latin America and the Caribbean: Challenges and Strategies, EPTD Discussion Paper 64 EPTD, IFPRI, Washington.

Rocha López, R., Boelens, R., Vos, J., Rap, E., 2019. Hydrosocial territories in dispute: flows of water and power in an interbasin transfer project in Bolivia. Water Altern. 12 (1), 267-284.

Rocha, R., Vincent, L., Rap, E., 2015. Re-engineering closing watersheds: the negotiated expansion of a dam-based irrigation system in Bolivia. Int. J. Water Resour. Dev. 31 (1), 50-63.

Rodríguez-de-Francisco, J.C., Boelens, R., 2015. Payment for environmental services: mobilising an epistemic community to construct dominant policy. Environ. Polit. 24 (3), 481-500.

Rodríguez-de-Francisco, J.C., Boelens, R., 2016. PES hydrosocial territories: de-territorialization and re-patterning of water control arenas in the Andean highlands. Water Int. 41 (1), 140-156.

Roth, D., Boelens, R., Zwarteveen, M., 2005. Liquid Relations. Contested Water Rights and Legal Complexity. Rutgers University Press, New Brunswick, New Jersey, London.

Roth, D., Boelens, R., Zwarteveen, M., 2015. Property, legal pluralism, and water rights: the critical analysis of water governance and the politics of recognizing "local" rights. J. Legal Pluralism Unofficial Law 47 (3), 456-475.

Saldías, C., Boelens, R., Wegerich, K., Speelman, S., 2012. Losing the watershed focus: a look at complex community-managed irrigation systems in Bolivia. Water Int. 37 (7), 744-759.

Salzgitter Colsult GmbH, 1991. Proyecto Punata Fase II. Informe Final. MACA - SNDC PRAV, Cochabamba, Bolivia.

Sax, J.L., 1990. The constitution, property rights and the future of water law. U. Colo. L. Rev 61, 257-282.

Schlager, E., Ostrom, E., 1992. Property-rights regimes and natural resources: a conceptual analysis. Land Econ. 68 (3), 249-262.

Seemann, M., 2016. Inclusive recognition politics and the struggle over hydrosocial territories in two Bolivian highland communities. Water Int. 41 (1), 157-172.

Sikor, T., Lund, C., 2009. Access and property: a question of power and authority. Dev. Change 40 (1), 1-22.

Spiertz, H.J., 2000. Water rights and legal pluralism: some basics of a legal anthropological approach. In: Bruns, B., Meinzen-Dick, R. (Eds.), Negotiating Water Rights. Vistaar Publications, New Delhi, pp. 162-199.

Swyngedouw, E., 1999. Modernity and hybridity: nature, regeneracionismo, and the production of the Spanish Waterscape, 1890-1930. Ann. Assoc. Am. Geogr. 89 (3), $443-465$.

Valladares, C., Boelens, R., 2017. Extractivism and the rights of nature: governmentality, 'convenient communities' and epistemic pacts in Ecuador. Environ. Polit. 26 (6), $1015-1034$.

Van der Ploeg, J.D., 2008. The New Peasantries. Struggles for Autonomy and Sustainability in an Era of Empire and Globalization. Earthscan, London, Sterling, VA.

Van Koppen, B., 1998. Water rights, gender, and poverty alleviation. Inclusion and exclusion of women and men smallholders in public irrigation infrastructure development. Agric. Hum. Values 15 (4), 361-374.

Vos, H.D., Boelens, R., Bustamante, R., 2006. Formal law and local water control in the andean region: a fiercely contested field. Int. J. Water Resour. Dev. 22 (1), 37-48.

Vos, J., Boelens, R., 2014. Sustainability standards and the water question. Dev. Change 45 (2), 205-230.

Vos, J., Hinojosa, L., 2016. Virtual water trade and the contestation of hydrosocial territories. Water Int. 41 (1), 37-53.

VRHyR, 2013. Agenda del Riego 2025. Ministerio de Medio Ambiente y Agua - VRHyR, Cochabamba, Bolivia p. 36.

Wilson, N.J., Inkster, J., 2018. Respecting water: indigenous water governance, ontologies, and the politics of kinship on the ground. Environ. Plann. E: Nat. Space 1 (4), 516-538.

Zwarteveen, M., Roth, D., Boelens, R., 2005. Water rights and legal pluralism: beyond analysis and recognition. In: Roth, D., Boelens, R., Zwarteveen, M. (Eds.), Liquid Relations. Contested Water Rights and Legal Complexity. Rutgers University Press, New Brunswick, New Jersey, London, pp. 254-268. 